\title{
Parametric Optimization of Cultural Conditions for Carboxymethyl Cellulase Production Using Pretreated Rice Straw by Bacillus sp. 313SI under Stationary and Shaking Conditions
}

\author{
Varsha Goyal, ${ }^{1}$ Arpana Mittal,, Anish Kumari Bhuwal, ${ }^{1}$ \\ Gulab Singh, ${ }^{1}$ Anita Yadav, ${ }^{2}$ and Neeraj Kumar Aggarwal ${ }^{1}$ \\ ${ }^{1}$ Department of Microbiology, Kurukshetra University, Kurukshetra, Haryana 136119, India \\ ${ }^{2}$ Department of Biotechnology, Kurukshetra University, Kurukshetra, Haryana 136119, India
}

Correspondence should be addressed to Neeraj Kumar Aggarwal; neerajkuk26@rediffmail.com

Received 26 November 2013; Revised 21 March 2014; Accepted 31 March 2014; Published 29 April 2014

Academic Editor: Goetz Laible

Copyright (C) 2014 Varsha Goyal et al. This is an open access article distributed under the Creative Commons Attribution License, which permits unrestricted use, distribution, and reproduction in any medium, provided the original work is properly cited.

\begin{abstract}
Carboxymethyl cellulase (CMCase) provides a key opportunity for achieving tremendous benefits of utilizing rice straw as cellulosic biomass. Out of total 80 microbial isolates from different ecological niches one bacterial strain, identified as Bacillus sp. 313SI, was selected for CMCase production under stationary as well as shaking conditions of growth. During two-stage pretreatment, rice straw was first treated with $0.5 \mathrm{M} \mathrm{KOH}$ to remove lignin followed by treatment with $0.1 \mathrm{~N} \mathrm{H}_{2} \mathrm{SO}_{4}$ for removal of hemicellulose. The maximum carboxymethyl cellulase activity of $3.08 \mathrm{U} / \mathrm{mL}$ was obtained using $1 \%(\mathrm{w} / \mathrm{v})$ pretreated rice straw with $1 \%$ (v/v) inoculum, $\mathrm{pH} 8.0$ at $35^{\circ} \mathrm{C}$ after $60 \mathrm{~h}$ of growth under stationary conditions, while the same was obtained as $4.15 \mathrm{U} / \mathrm{mL}$ using $0.75 \%$ $(\mathrm{w} / \mathrm{v})$ pretreated substrate with $0.4 \%(\mathrm{v} / \mathrm{v})$ inoculum, $\mathrm{pH} 8.0$ at $30^{\circ} \mathrm{C}$, under shaking conditions of growth for $48 \mathrm{~h}$. For maximum titre of CMCase carboxymethyl cellulose was optimized as the best carbon source under both cultural conditions while ammonium sulphate and ammonium nitrate were optimized as the best nitrogen sources under stationary and shaking conditions, respectively. The present study provides the useful data about the optimized conditions for CMCase production by Bacillus sp. 313SI from pretreated rice straw.
\end{abstract}

\section{Introduction}

Lignocellulosic materials from agriculture and forest management are the largest sources of hexose (C-6) and pentose (C-5) sugars with a potential for the production of biofuels, chemicals, and other economic by-products [1]. Lignocellulosic biomass is mainly composed of plant cell walls, with the structural carbohydrates cellulose and hemicellulose and heterogeneous phenolic polymer lignin as its primary components [2]. The lignocellulosic substrates include woody substrates such as hardwood (birch and aspen, etc.), softwood (spruce and pine, etc.), agroresidues (wheat straw, sugarcane bagasse, corn stover, etc.), dedicated energy crops (switch grass, miscanthus, etc.), weedy materials (Eicchornia crassipes, Lantana camara, etc.), and municipal solid waste (food and kitchen waste, etc.) [3]. Lignocellulosic biomass is composed of cellulose, hemicellulose, and lignin, as well as other minor components. The recalcitrance of lignocellulosic biomass to enzyme such as the interaction between cellulose and hemicellulose and degree of lignifications necessitates a pretreatment process for increasing its enzymatic digestibility. Pretreatment of biomass plays a critical role in producing materials with acceptable enzymatic digestibility and subsequent fermentability for the production of cellulosic ethanol or other advanced biofuels such as butanol derived from biomass.

Rice straw is an attractive lignocellulosic material for bioethanol production since it is one of the most abundant renewable resources [4] with annual productivity of around 800 million metric tonnes that corresponds with large 
production of rice straw [5]. For every ton of harvested grain, about 1.35 tons of rice straw remain in the field which generate huge amount of straw annually [6]. Disposal of rice straw is a huge problem as usage of rice straw in biological process, such as composting and biogas production, is limited by slow degradation in bioconverting process [7]. Moreover, it cannot be used as animal feed due to its low digestibility, low protein, and high lignin and silica content [8]. Rice straw is composed of $40 \%$ cellulose, $24 \%$ hemicellulose, and $25 \%$ lignin [9] so it requires a basic step of pretreatment for breakage of lignin and exposure of cellulose and hemicellulose for enzymatic saccharification. Several pretreatment processes including organosolvent [4], ultrasonication [10], alkali [11], steam explosion [12], microwave assisted alkali treatment [13], microwave assisted organic acid treatment [14], hot compress water [15], proton beam radiation [16], ammonia and ionic liquid [17], and acid [18] have been reported for rice straw.

Cellulases are inducible enzymes which are synthesized by microorganisms during their growth on cellulosic materials [19]. The complete enzymatic hydrolysis of cellulosic materials needs different types of cellulase, endoglucanase $(1,4$ $\beta$-d-glucan-4-glucanohydrolase; EC 3.2.1.4), exocellobiohydrolase $(1,4-\beta$-d-glucan glucohydrolase; EC 3.2.1.74), and $\beta$ glucosidase ( $\beta$-d-glucoside glucohydrolase; EC 3.2.1.21) [20]. Microorganisms are considered to be the main source of cellulases with novel and high specific activities. Microbial sources are the most economic and available sources because microorganisms can grow on inexpensive media such as agriculture and food industries by-products [21]. Various bacteria, actinomycetes, and filamentous fungi produce extracellular cellulases when grown on cellulosic substrates though many actinomycetes have been reported to have less cellulase activity than moulds [22]. Chaetomium, Fusarium, Trichoderma, Penicillium, and Aspergillus are some of the reported fungal species and Trichonympha, Clostridium, Actinomycetes, Bacteroides succinogenes, Butyrivibrio fibrisolvens, and Ruminococcus albus are some of the reported bacterial species responsible for cellulosic biomass hydrolysation [23]. Due to increasing demand for energy and the fast depleting petroleum resources there is an increased interest in alternative fuels, especially liquid transportation fuels from lignocelluloses, which led to a new dawn in cellulase research. Various kinds of value added products such as ethanol, organic acids, enzymes, and other chemicals can be made by enzymic hydrolysis of cellulosics; of these processes, ethanol has received the maximum attention as an alternative to gasoline in today's environment [24]. The aim of the present study was to optimize process parameters for alkali assisted acid pretreatment of rice straw for carboxymethyl cellulase enzyme production by Bacillus sp. 313SI under stationary and shaking conditions.

\section{Materials and Methods}

2.1. Isolation of Bacterial Strain for CMCase Production. Bacterial strains having cellulolytic potential were screened from the soil samples of different niches such as sugarcane field, rice field, paper industry, cattle shed, rotten fruits and vegetables, and samples of cattle dung. Isolation was done by dilution plate method on a carboxymethyl cellulose agar (CMC) medium (Hi media, India) $\left(\mathrm{NaNO}_{3}-2.0 \mathrm{~g} / \mathrm{L}, \mathrm{K}_{2} \mathrm{HPO}_{4}-1.0 \mathrm{~g} / \mathrm{L}\right.$, $\mathrm{MgSO}_{4} \cdot 7 \mathrm{H}_{2} \mathrm{O}-0.5 \mathrm{~g} / \mathrm{L}, \mathrm{KCl}-0.5 \mathrm{~g} / \mathrm{L}, \mathrm{CMC}-5.0 \mathrm{~g} / \mathrm{L}$, Agar-2\%, $\mathrm{pH}$ 8.0). Screening for cellulolytic activity was followed by visualizing the hydrolysis zone, when the plates were flooded with an aqueous solution of $0.1 \%$ Congo red for $15 \mathrm{~min}$ and washed with $1 \mathrm{M} \mathrm{NaCl}$ [25]. The isolated colonies on these plates were maintained on CMC agar slants at $4^{\circ} \mathrm{C}$ for further analysis.

2.2. Enzyme Assay. Carboxymethyl cellulase activity was assayed by the DNS (3, 5-dinitrosalicylic acid) method [26]. The reaction mixture contained $900 \mu \mathrm{L}$ of substrate (carboxymethyl cellulose in $10 \mathrm{mM}$ Sodium phosphate buffer $\mathrm{pH} 7.0$ ) and $100 \mu \mathrm{L}$ of crude enzyme was incubated at $30^{\circ} \mathrm{C}$ for $60 \mathrm{~min}$. An appropriate control which contained $100 \mu \mathrm{L}$ of distilled water instead of crude enzyme extract was also run along with the test. The reaction was terminated by adding $3 \mathrm{~mL}$ of 3, 5-dinitrosalicylic acid reagent. The tubes were incubated for $15 \mathrm{~min}$ in a boiling water bath for color development and were cooled rapidly. The activity of reaction mixture was measured against a reagent blank at $540 \mathrm{~nm}$. The concentration of glucose released by enzyme was determined by comparing against a standard curve constructed similarly with known concentrations of glucose. One unit of enzyme activity is defined as the amount of enzyme that liberates $1 \mu \mathrm{g}$ of glucose per minute under the assay conditions.

2.3. Pretreatment of Rice Straw. The main components of untreated rice straw were determined to be $38.40 \%$ cellulose, $24 \%$ hemicelluloses, and 19\% lignin using standard procedure [27]. The rice straw was first pretreated with $0.5 \mathrm{M} \mathrm{KOH}$ for $4 \mathrm{~h}$ at room temperature at the ratio of $1: 10$ for substrate and $\mathrm{KOH}$ solution. The pretreated solid was washed with water till neutrality, filtered, and dried. The solid was further treated by $0.1 \mathrm{~N} \mathrm{H}_{2} \mathrm{SO}_{4}$ for $1 \mathrm{~h}$ at room temperature and then autoclave at $121^{\circ} \mathrm{C}$ and 15 psi pressure for 15 minutes. The pulp was washed with water till neutrality, filtered, dried, and stored at room temperature for further use.

\subsection{Optimization of CMCase Production under Stationary} and Shaking Conditions. Various physicochemical parameters were analyzed under stationary and shaking conditions for maximum carboxymethyl cellulase enzyme production by Bacillus sp. 313SI. The various parameters that were optimized were pretreated rice straw concentration $(0.25-$ $2.0 \% \mathrm{w} / \mathrm{v})$, inoculum concentration $(0.25-1.0 \% \mathrm{v} / \mathrm{v})$, incubation temperature $\left(20-60^{\circ} \mathrm{C}\right)$, incubation $\mathrm{pH}(5.0-9.0)$, and various additives such as carbon sources (galactose, maltose, carboxymethyl cellulose, starch, mannitol, and cellulose powder) and nitrogen sources (ammonium nitrate, ammonium sulphate, ammonium chloride, beef, tryptone, urea, and potassium nitrate).

2.5. Statistical Analysis. The optimization results for different parameters were analyzed using statistical packages system 
software (SPSS; 16.0). The ANOVA with post hoc analysis was applied for within-group comparison. The level of significance was set at 0.05 .

\section{Result and Discussion}

3.1. Isolation and Identification of Isolated Bacterial Strain. The bacterial strain with maximum carboxymethyl cellulase activity was isolated from cattle shed soil and identified as Bacillus sp. 313 SI by Xcelris Labs Ltd., Ahmadabad, India, and has been given National Centre for Biotechnology Information (NCBI) accession number JQ734551.1.

3.2. Alkali Assisted Acidic Pretreatment of Rice Straw. The effect of alkali assisted acidic pretreatment on chemical composition of rice straw such as cellulose, hemicelluloses, and lignin was analyzed. It was determined that cellulose, hemicelluloses, and lignin content of obtained alkali assisted acidic pretreated rice straw was $59.5 \%, 8.26 \%$, and $5.17 \%$, respectively. Taherzadeh and Karimi [28] have reported that efficient delignifier should remove a maximum of lignin and minimum of sugars. Pretreatment of lignocelluloses with alkali overcomes the lignin barrier, by dissolving the lignin caused by the breakdown of ether linkages [29]. Lu et al. [30] have examined that hemicelluloses can effectively solubilise and hydrolyze into monomeric sugars and soluble oligomers by dilute sulphuric acid pretreatment. Chandel et al. [31] reported $\mathrm{NH}_{4} \mathrm{OH}$ mediated delignification of sugarcane bagasse which resulted in $41.51 \%$ lignin removal as compared to untreated substrate which later improved the enzymatic saccharification of substrate employing commercial cellulase.

3.3. Effect of Substrate Concentration. Alkali and acid pretreated rice straw was used to analyze the effect of substrate concentration on carboxymethyl cellulase enzyme production by Bacillus sp. 313SI. As shown in Figure 1 substrate concentration at $1 \% \mathrm{w} / \mathrm{v}$ and $0.75 \% \mathrm{w} / \mathrm{v}$ was found to be optimized for maximum cellulase activity of $2.12 \pm 0.04 \mathrm{U} / \mathrm{mL}$ and $2.85 \pm 0.06 \mathrm{U} / \mathrm{mL}$ under stationary and shaking conditions, respectively. The ANOVA for the data on CMCase as a function of variation due to different concentrations of substrate under stationary conditions $(F=327.91 ; P<$ $0.0001)$ and shaking conditions $(F=325.55 ; P<0.0001)$ is statistically significant. Immanuel et al. [32] reported the maximum enzymatic activity with $1.5 \%$ pretreated coir fiber.

3.4. Inoculum Concentration. Effective inoculum concentration $(0.25-1.0 \% \mathrm{w} / \mathrm{v})$ for carboxymethyl cellulase enzyme production by Bacillus sp. 313SI was evaluated for stationary and shaking conditions. Maximum carboxymethyl cellulase enzyme activity of $2.25 \pm 0.06 \mathrm{U} / \mathrm{mL}$ was obtained with $1 \% \mathrm{w} / \mathrm{v}$ inoculum concentration under stationary conditions while under shaking conditions $0.4 \%$ inoculum concentration had showed the maximum carboxymethyl cellulase enzyme activity of $2.92 \pm 0.05 \mathrm{U} / \mathrm{mL}$ as shown in Figure 2 . The ANOVA for the data on CMCase as a function of variation due to different concentrations of inoculum under stationary conditions $(F=475.68 ; P<0.0001)$ and shaking conditions

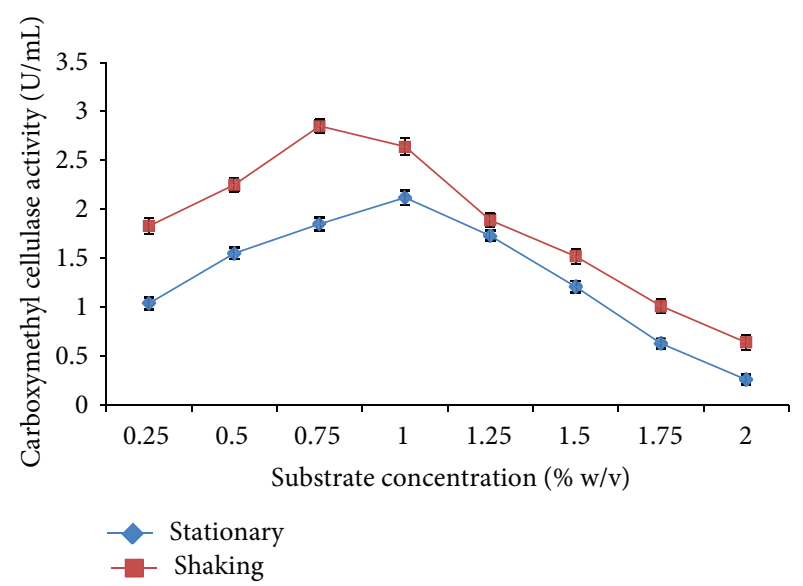

FIGURE 1: Effect of substrate concentration on carboxymethyl cellulase enzyme production by Bacillus sp. 313SI under stationary and shaking conditions of growth. Values in figure are means of three replicates with standard deviation.

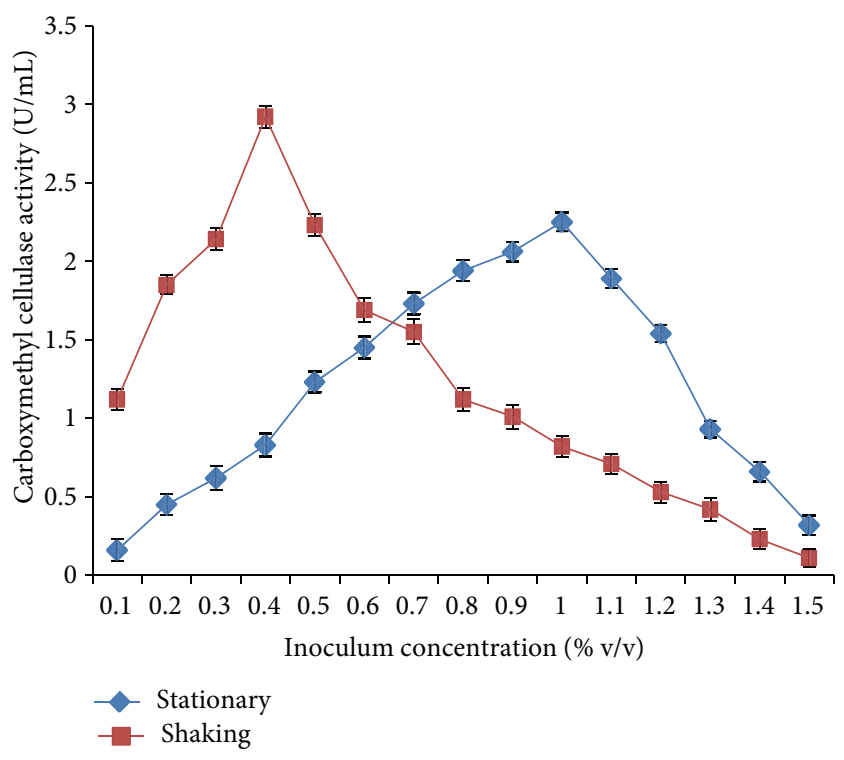

FIgURE 2: Effect of inoculum concentration on carboxymethyl cellulase enzyme production by Bacillus sp. 313SI under stationary and shaking conditions of growth. Values in figure are means of three replicates with standard deviation.

$(F=584.09 ; P<0.0001)$ is statistically significant. Bacillus subtilis and Bacillus circulans showed maximum carboxymethyl cellulase enzyme production up to $3 \%$ inoculum size [33]. Abou-Taleb et al. [34] also reported that $B$. alcalophilus $\mathrm{S} 39$ and $B$. amyloliquefaciens $\mathrm{C2}_{3}$ showed maximum carboxymethyl cellulase enzyme production at 3.0\% inoculum size. Das et al. [35] reported optimum inoculum size of $7 \%$ for maximum carboxymethyl cellulase enzyme production at $42^{\circ} \mathrm{C}$ by Bacillus sp.

3.5. Incubation Time. To determine the optimum incubation time for carboxymethyl cellulase enzyme production by $\mathrm{Ba}$ cillus sp. 313SI from pretreated rice straw time course of 


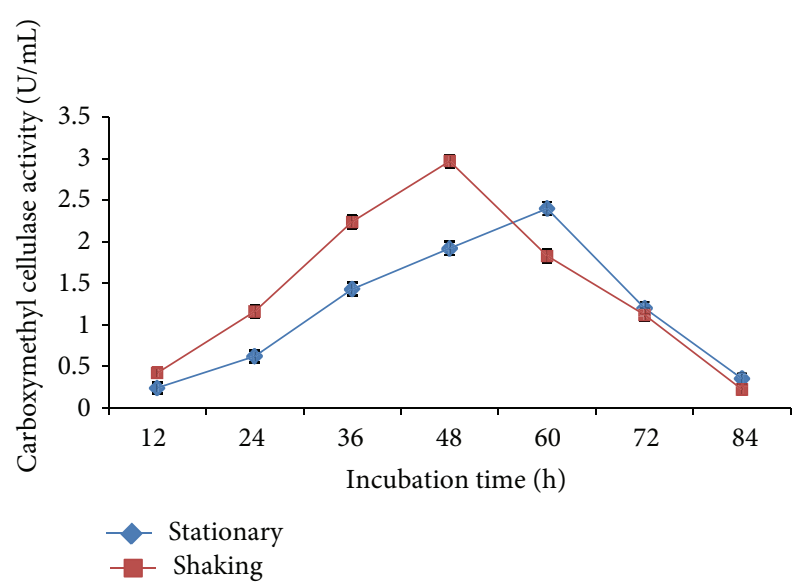

Figure 3: Effect of incubation time on carboxymethyl cellulase enzyme production by Bacillus sp. 313SI under stationary and shaking conditions of growth. Values in figure are means of three replicates with standard deviation.

cultivation was recorded up to $84 \mathrm{~h}$. Carboxymethyl cellulase enzyme production was increased with increase in incubation time and maximum CMCase activity of $2.40 \pm$ $0.07 \mathrm{U} / \mathrm{mL}$ was optimized at $60 \mathrm{~h}$ under stationary conditions and $2.97 \pm 0.06 \mathrm{U} / \mathrm{mL}$ at $48 \mathrm{~h}$ under shaking conditions as shown in Figure 3. The ANOVA for the data on CMCase as a function of variation due to different time of incubation under stationary conditions $(F=890.75 ; P<0.0001)$ and shaking conditions $(F=947.52 ; P<0.0001)$ is statistically significant. Shabeb et al. [36] found maximum carboxymethyl cellulase enzyme activity in Bacillus subtilis $\mathrm{KO}$ strain after $24 \mathrm{~h}$ of incubation period. Heck et al. [37] and Amritkar et al. [38] found maximum carboxymethyl cellulase enzyme activity in Bacillus spp. B21, Bacillus pumilus, and Bacillus subtilis after $72 \mathrm{~h}$ of incubation. Poorna and Prema [39] reported the maximum carboxymethyl cellulase enzyme activity in Bacillus pumilus after $120 \mathrm{~h}$ of incubation.

3.6. Initial $\mathrm{pH}$. The initial $\mathrm{pH}$ of production medium plays an important role in the production of carboxymethyl cellulase enzyme. The effect of different $\mathrm{pH}$ range was optimized on carboxymethyl cellulase enzyme production from Bacillus $s p$. $313 S I$ from pretreated rice straw. Maximum CMCase activity of $2.67 \pm 0.06 \mathrm{U} / \mathrm{mL}$ was obtained at $\mathrm{pH} 8.0$ under stationary conditions while under shaking conditions this is $3.50 \pm$ $0.07 \mathrm{U} / \mathrm{mL}$ as shown in Figure 4. The ANOVA for the data on CMCase as a function of variation due to different $\mathrm{pH}$ under stationary conditions $(F=627.75 ; P<0.0001)$ and shaking conditions $(F=741.86 ; P<0.0001)$ is statistically significant. These results are in agreement with those of Immanuel et al. [32] who found the cellulolytic enzyme, endoglucanase, obtained from Cellulomonas, Bacillus, and Micrococcus spp. hydrolyzed substrate in the $\mathrm{pH}$ range of 4.0 to 9.0 , with maximum activity transpiring at $\mathrm{pH}$ 7. Ray et al. [33] reported that $\mathrm{pH}$ 7-7.5 was more suitable for optimization of cellulase production by Bacillus subtilis and B. circulans.

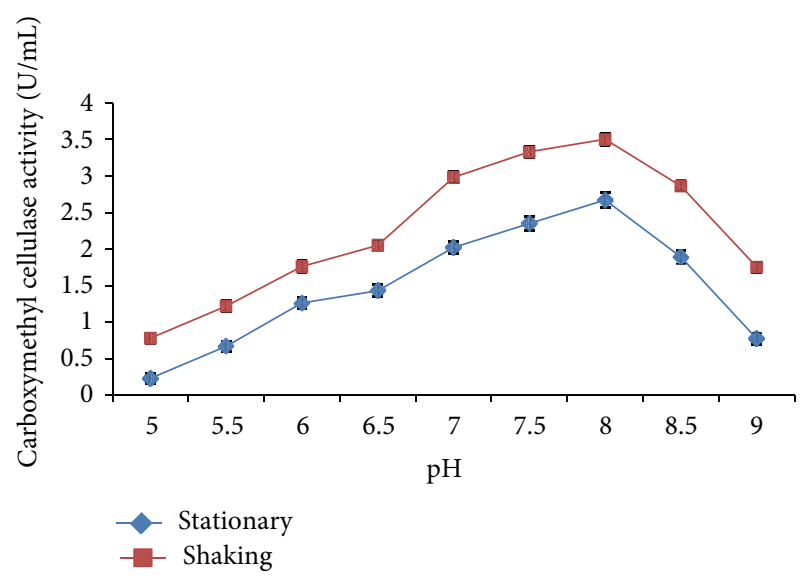

FIGURE 4: Effect of $\mathrm{pH}$ on carboxymethyl cellulase enzyme production by Bacillus sp. 313SI under stationary and shaking conditions of growth. Values in figure are means of three replicates with standard deviation.

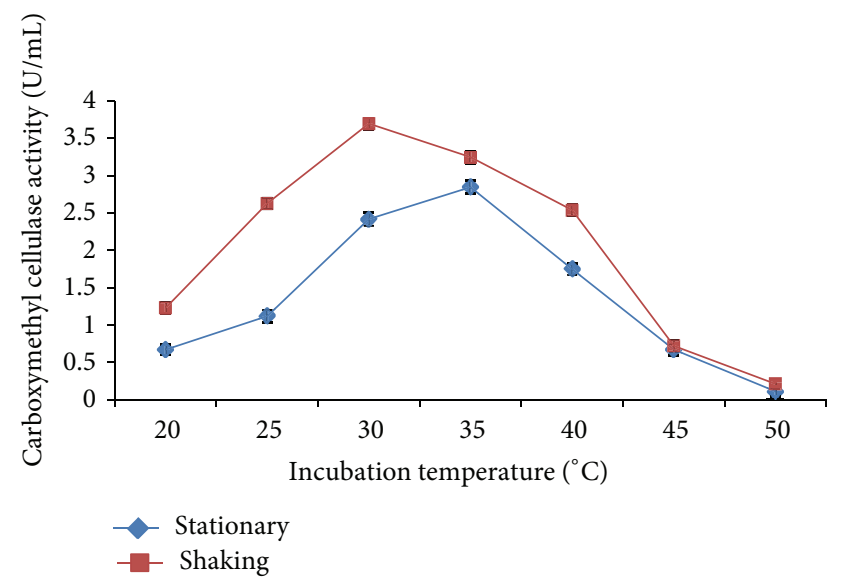

FIGURE 5: Effect of temperature on carboxymethyl cellulase enzyme production by Bacillus sp. $313 S I$ under stationary and shaking conditions of growth. Values in figure are means of three replicates with standard deviation.

Gautam et al. [40] found the optimum $\mathrm{pH}$ of 7.5 for maximum carboxymethyl cellulase enzyme activity by Pseudomonas sp.

3.7. Incubation Temperature. The effect of temperature varying between $20^{\circ} \mathrm{C}$ and $50^{\circ} \mathrm{C}$ on production of carboxymethyl cellulase enzyme was studied. Bacillus sp. 313SI showed maximum carboxymethyl cellulase enzyme activity of $2.85 \pm$ $0.05 \mathrm{U} / \mathrm{mL}$ under stationary conditions at $35^{\circ} \mathrm{C}$ and $3.70 \pm$ $0.06 \mathrm{U} / \mathrm{mL}$ under shaking conditions at $30^{\circ} \mathrm{C}$ as shown in Figure 5. The ANOVA for the data on CMCase as a function of variation due to different temperatures under stationary conditions $(F=115.0 ; P<0.0001)$ and shaking conditions $(F=$ $184.4 ; P<0.0001)$ is statistically significant. These results are close to those of Kanmani et al. [21] who found that the carboxymethyl cellulase enzyme produced by Bacillus pumilis showed the optimum temperature of $35^{\circ} \mathrm{C}$. Rastogi et al. [41] 


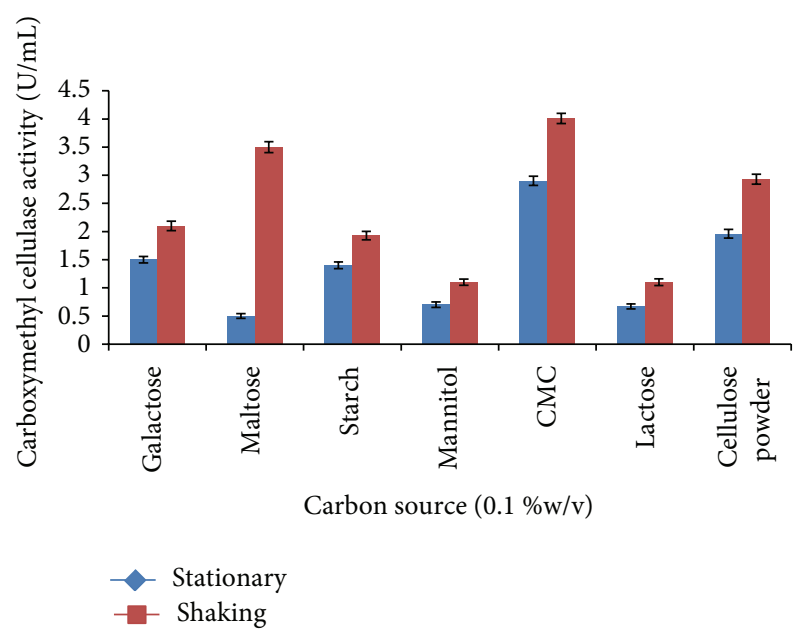

FIGURE 6: Effect of different carbon sources on carboxymethyl cellulase enzyme production by Bacillus sp. 313SI under stationary and shaking conditions of growth. Values in figure are means of three replicates with standard deviation.

reported two strains DUSELR7 and DUSELR13 as mesophilic carboxymethyl cellulase enzyme producer at $37^{\circ} \mathrm{C}$.

3.8. Carbon and Nitrogen Sources. Supplementation of carbon and nitrogen sources in medium showed a significant increase in carboxymethyl cellulase enzyme production by $\mathrm{Ba}$ cillus sp. 313SI from pretreated rice straw under stationary and shaking conditions. Effect of different carbon sources $(0.1 \%$ $\mathrm{w} / \mathrm{v}$ ) on the production of carboxymethyl cellulase enzyme was evaluated as shown in Figure 6.

Carboxymethyl cellulose was optimized as best carbon source for both conditions. The maximum carboxymethyl cellulase enzyme activity of $2.90 \pm 0.13 \mathrm{U} / \mathrm{mL}$ was recorded under stationary conditions and $4.01 \pm 0.06 \mathrm{U} / \mathrm{mL}$ was recorded under shaking conditions. The ANOVA for the data on CMCase as a function of variation due to different carbon sources under stationary conditions $(F=161.41 ; P<$ $0.0001)$ and shaking conditions $(F=223.16 ; P<0.0001)$ is statistically significant. Carboxymethyl cellulose was most effective as a sole carbon source for carboxymethyl cellulase enzyme production by Bacillus alcalophilus S39 [34]. Carboxymethyl cellulose was the best carbon source followed by cellulose for carboxymethyl cellulase enzyme production [42, 43]. $1 \%(\mathrm{w} / \mathrm{v})$ carboxymethyl cellulose was found to be optimal for carboxymethyl cellulase enzyme production in Bacillus sp. [44].

Similarly the influence of different nitrogen sources $(0.1 \%$ $\mathrm{w} / \mathrm{v}$ ) on carboxymethyl cellulase enzyme production was evaluated as shown in Figure 7. The results showed that Bacillus sp. 313SI gave maximum yield of carboxymethyl cellulase enzyme by added ammonium sulphate, that is, $3.08 \pm$ $0.07 \mathrm{U} / \mathrm{mL}$ in medium for stationary conditions and $4.15 \pm$ $0.06 \mathrm{U} / \mathrm{mL}$ in medium for shaking conditions. The ANOVA for the data on CMCase as a function of variation due to different nitrogen sources under stationary conditions $(F=$ 379.0; $P<0.0001)$ and shaking conditions $(F=492.7 ; P<$

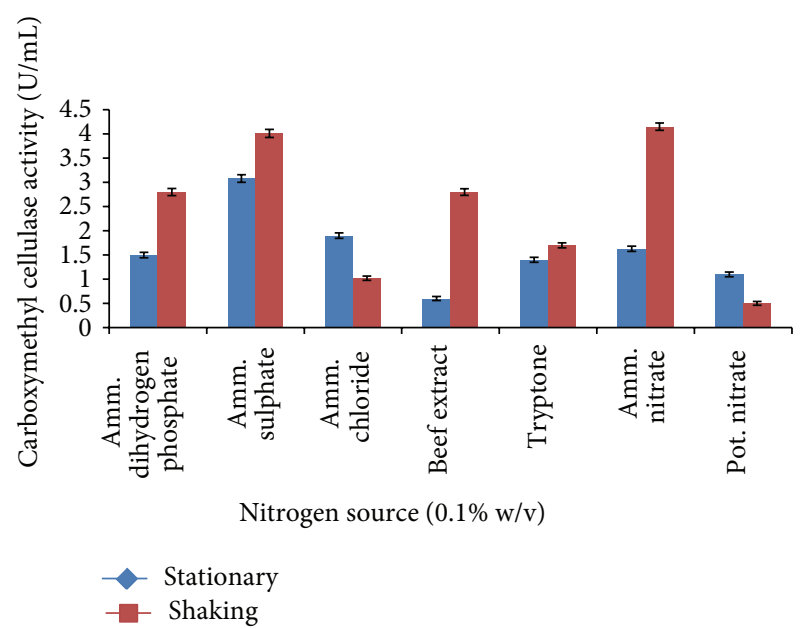

FIGURE 7: Effect of different nitrogen sources on carboxymethyl cellulase enzyme production by Bacillus sp. 313SI under stationary and shaking conditions of growth. Values in figure are means of three replicates with standard deviation.

0.0001) is statistically significant. Balamurugan et al. [45] found that ammonium sulphate and ammonium nitrate are optimum nitrogen sources for carboxymethyl cellulase enzyme in CDB7 and CDB13 isolates at $30^{\circ} \mathrm{C}$. Peptone was optimized as the best nitrogen source for carboxymethyl cellulase enzyme production by Bacillus sp. at $42^{\circ} \mathrm{C}$ [35].

\section{Conclusion}

The data gathered in this study provides evidence for CMCase production by Bacillus sp. 313SI from alkali assisted acidic pretreated rice straw. Qualitative effect of some carbon and nitrogen sources, incubation time, $\mathrm{pH}$, inoculum concentration, and incubation temperature was studied and optimized for CMCase production by Bacillus sp. 313SI. High titre of CMCase production by Bacillus sp. 313SI using pretreated cost-effective agroresidue (rice straw) at $\mathrm{pH} 8.0$ and $30^{\circ} \mathrm{C}$ made it as a potential producer of mesoalkalophilic cellulases which can find wide applications involving saccharification in various lignocellulosic based industries particularly bioethanol industry.

\section{Conflict of Interests}

The authors declare that there is no conflict of interests regarding the publication of this paper.

\section{Acknowledgments}

Authors gratefully acknowledge the financial assistance from University Grant Commission (UGC), New Delhi, India, and also acknowledge the assistance from Haryana State Council of Science and Technology (HSCST). University Research Scholarship (URS) awarded to Varsha Goyal by Kurukshetra University is kindly acknowledged. 


\section{References}

[1] P. Kaparaju, M. Serrano, A. B. Thomsen, P. Kongjan, and I. Angelidaki, "Bioethanol, biohydrogen and biogas production from wheat straw in a biorefinery concept," Bioresource Technology, vol. 100, no. 9, pp. 2562-2568, 2009.

[2] X. Q. Zhao, L. H. Zi, F. W. Bai et al., "Bioethanol from lignocellulosic biomass," Advances in Biochemical Engineering/Biotechnology, vol. 128, pp. 25-41, 2012.

[3] A. K. Chandel and O. V. Singh, "Weedy lignocellulosic feedstock and microbial metabolic engineering: advancing the generation of "Biofuel," Applied Microbiology and Biotechnology, vol. 89, no. 5, pp. 1289-1303, 2011.

[4] R. Sindhu, P. Binod, K. U. Janu, R. K. Sukumaran, and A. Pandey, "Organosolvent pretreatment and enzymatic hydrolysis of rice straw for the production of bioethanol," World Journal of Microbiology and Biotechnology, vol. 28, no. 2, pp. 473-483, 2012.

[5] L. Wati, S. Kumari, and B. S. Kundu, "Paddy straw as substrate for ethanol production," Indian Journal of Microbiology, vol. 47, no. 1, pp. 26-29, 2007.

[6] K. L. Kadam, L. H. Forrest, and W. A. Jacobson, "Rice straw as a lignocellulosic resource: collection, processing, transportation, and environmental aspects," Biomass and Bioenergy, vol. 18, no. 5, pp. 369-389, 2000.

[7] S. M. Hosseini, H. A. Aziz, S. Syafalni, and A. Mojiri, "Enhancement of rice straw biodegradability by alkaline and acid thermochemical pretreatment process: optimization by response surface methodology (RSM)," Caspian Journal of Applied Sciences Research, vol. 1, no. 12, pp. 8-24, 2012.

[8] H. Kausar, M. Sariah, H. M. Saud, M. Z. Alam, and M. R. Ismail, "Isolation and screening of potential actinobacteria for rapid composting of rice straw," Biodegradation, vol. 22, no. 2, pp. 367375, 2011.

[9] H.-K. Kang, N. M. Kim, G. J. Kim et al., "Enhanced saccharification of rice straw using hypochlorite-hydrogen peroxide," Biotechnology and Bioprocess Engineering, vol. 16, no. 2, pp. 273281, 2011.

[10] N. Yoswathana, P. Phuriphipat, P. Treyawutthiwat, and M. N. Eshtiaghi, "Bioethanol production from rice straw," Energy Research Journal, vol. 1, no. 1, pp. 26-31, 2010.

[11] N. Sarkar and K. Aikat, "Alkali pretreatment of rice straw and enhanced cellulase production by a locally isolated fungus Aspergillus fumigatus NITDGPKA3," Journal of Microbiology and Biotechnology Research, vol. 2, no. 5, pp. 717-726, 2012.

[12] M. Taniguchi, D. Takahashi, D. Watanabe et al., "Effect of steam explosion pretreatment on treatment with Pleurotus ostreatus for the enzymatic hydrolysis of rice straw," Journal of Bioscience and Bioengineering, vol. 110, no. 4, pp. 449-452, 2010.

[13] J. Cheng, H. Su, J. Zhou, W. Song, and K. Cen, "Microwaveassisted alkali pretreatment of rice straw to promote enzymatic hydrolysis and hydrogen production in dark- and photofermentation," International Journal of Hydrogen Energy, vol. 36, no. 3, pp. 2093-2101, 2011.

[14] G. Gong, D. Liu, and Y. Huang, "Microwave-assisted organic acid pretreatment for enzymatic hydrolysis of rice straw," Biosystems Engineering, vol. 107, no. 2, pp. 67-73, 2010.

[15] G. Yu, S. Yano, H. Inoue, S. Inoue, T. Endo, and S. Sawayama, "Pretreatment of rice straw by a hot-compressed water process for enzymatic hydrolysis," Applied Biochemistry and Biotechnology, vol. 160, no. 2, pp. 539-551, 2010.
[16] S. B. Kim, J. S. Kim, J. H. Lee, S. W. Kang, C. Park, and S. W. Kim, "Pretreatment of rice straw by proton beam irradiation for efficient enzyme digestibility," Applied Biochemistry and Biotechnology, vol. 164, no. 7, pp. 1183-1191, 2011.

[17] T. A. D. Nguyen, K. R. Kim, S. J. Han et al., "Pretreatment of rice straw with ammonia and ionic liquid for lignocellulose conversion to fermentable sugars," Bioresource Technology, vol. 101, no. 19, pp. 7432-7438, 2010.

[18] J. Sumphanwanich, N. Leepipatpiboon, T. Srinorakutara, and A. Akaracharanya, "Evaluation of dilute-acid pretreated bagasse, corn cob and rice straw for ethanol fermentation by Saccharomyces cerevisiae," Annals of Microbiology, vol. 58, no. 2, pp. 219-225, 2008.

[19] S. M. Lee and Y. M. Koo, "Pilot-scale production of cellulase using Trichoderma reesei Rut C-30 in fed-batch mode," Journal of Microbiology and Biotechnology, vol. 11, no. 2, pp. 229-233, 2001.

[20] J. C. Yi, J. C. Sandra, A. B. John, and T. C. Shu, "Production and distribution of endoglucanase, cellobiohydrolase, and $\beta$ glucosidase components of the cellulolytic system of Volvariella volvacea, the edible straw mushroom," Applied and Environmental Microbiology, vol. 65, no. 2, pp. 553-559, 1999.

[21] R. Kanmani, P. Vijayabaskar, and S. Jayalakshmi, "Saccharification of banana-agro waste and clarification of apple juice by cellulase enzyme produced from Bacillus pumilis," World Applied Sciences Journal, vol. 12, no. 11, pp. 2120-2128, 2011.

[22] M. Ishaque and D. Kluepfel, "Cellulase complex of a mesophilic Streptomyces strain," Canadian Journal of Microbiology, vol. 26, no. 2, pp. $183-189,1980$.

[23] P. Gupta, K. Samant, and A. Sahu, "Isolation of cellulosedegrading bacteria and determination of their cellulolytic potential," International Journal of Microbiology, vol. 2012, Article ID 578925, 5 pages, 2012.

[24] A. K. Chandel, G. Chandrasekhar, M. B. Silva, and S. S. da Silva, "The realm of cellulases in biorefinery development," Critical Reviews in Biotechnology, vol. 32, no. 3, pp. 187-202, 2012.

[25] K. Apun, B. C. Jong, and M. A. Salleh, "Screening and isolation of a cellulolytic and amylolytic Bacillus from sago pith waste," Journal of General and Applied Microbiology, vol. 46, no. 5, pp. 263-267, 2000.

[26] G. L. Miller, "Use of dinitrosalicylic acid reagent for determination of reducing sugar," Analytical Chemistry, vol. 31, no. 3, pp. 426-428, 1959.

[27] H. D. Goerging and J. P. van Soest, Forage Fiber Analysis, US Department of Agriculture, Agricultural Research Service, Washington, DC, USA, 1975.

[28] M. J. Taherzadeh and K. Karimi, "Acid based hydrolysis process for bioethanol production from lignocellulosic materials: a review," Bioresources, vol. 2, no. 3, pp. 472-499, 2007.

[29] J. Lee, "Biological conversion of lignocellulosic biomass to ethanol," Journal of Biotechnology, vol. 56, no. 1, pp. 1-24, 1997.

[30] X. B. Lu, Y. M. Zhang, J. Yang, and Y. Liang, "Enzymatic hydrolysis of corn stover after pretreatment with dilute sulfuric acid," Chemical Engineering \& Technology, vol. 30, no. 7, pp. 938944, 2007.

[31] A. K. Chandel, F. A. F. Antunes, M. B. Silva, and S. S. da Silva, "Unraveling the structure of sugarcane bagasse after soaking in concentrated aqueous ammonia (SCAA) and ethanol production by Scheffersomyces (Pichia) stipitis," Biotechnology for Biofuels, vol. 6, article 102, 2013. 
[32] G. Immanuel, R. Dhanusha, P. Prema, and A. Palavesam, "Effect of different growth parameters on endoglucanase enzyme activity by bacteria isolated from coir retting effluents of estuarine environment," International Journal of Environmental Science and Technology, vol. 3, no. 1, pp. 25-34, 2006.

[33] A. K. Ray, A. Bairagi, K. S. Ghosh, and S. K. Sen, "Optimization of fermentation conditions for cellulase production by Bacillus subtilis CY5 and Bacillus circulans TP3 isolated from fish gut," Acta Ichthyologica Et Piscatoria, vol. 37, no. 1, pp. 47-53, 2007.

[34] A. A. K. Abou-Taleb, W. A. Mashhoor, A. S. Nasr, M. S. Sharaf, and H. M. H. Abdel-Azeem, "Nutritional and environmental factors affecting cellulase production by two strains of cellulolytic Bacilli," Australian Journal of Basic and Applied Sciences, vol. 3, no. 3, pp. 2429-2436, 2009.

[35] A. Das, S. Bhattacharya, and L. Murali, "Production of cellulase from a thermophillic Bacillus sp. isolated from cow dung," American-Eurasian Journal of Agricultural \& Environmental Sciences, vol. 8, no. 6, pp. 685-691, 2010.

[36] M. S. A. Shabeb, M. A. M. Younis, F. F. Hezayen, and M. A. N. Eldein, "Production of cellulase in low-cost medium by Bacillus subtilis KO strain," World Applied Sciences Journal, vol. 8, no. 1, pp. 35-42, 2010.

[37] J. X. Heck, P. F. Hertz, and M. A. Z. Ayub, "Cellulase and xylanase production by isolated amazon Bacillus strains using soybean industrial residue based solid-state cultivation," Brazilian Journal of Microbiology, vol. 33, no. 3, pp. 213-218, 2002.

[38] N. Amritkar, N. M. Kamat, and A. Lali, "Expanded bed affinity purification of bacterial $\alpha$-amylase and cellulase on composite substrate analogue-cellulose matrices," Process Biochemistry, vol. 39, no. 5, pp. 565-570, 2004.

[39] C. A. Poorna and P. Prema, "Production of cellulase-free endoxylanase from novel alkalophilic thermotolerent Bacillus pumilus by solid-state fermentation and its application in waste paper recycling," Bioresource Technology, vol. 98, no. 3, pp. 485490, 2007.

[40] S. P. Gautam, P. S. Bundela, A. K. Pandey, J. Jamaluddin, M. K. Awasthi, and S. Sarsaiya, "Cellulase production by Pseudomonas sp. isolated from municipal solid waste compost," International Journal of Academic Research, vol. 2, no. 6, pp. 329-332, 2010.

[41] G. Rastogi, G. L. Muppidi, R. N. Gurram et al., "Isolation and characterization of cellulose-degrading bacteria from the deep subsurface of the Homestake gold mine, Lead, South Dakota, USA," Journal of Industrial Microbiology \& Biotechnology, vol. 36, no. 4, pp. 585-598, 2009.

[42] G. Narasimha, A. Sridevi, B. Viswanath, S. M. Chandra, and R. B. Reddy, "Nutrient effects on production of cellulolytic enzymes by Aspergillus niger," African Journal of Biotechnology, vol. 5, no. 5, pp. 472-476, 2006.

[43] A. P. Niranjane, P. Madhou, and T. W. Stevenson, "The effect of carbohydrate carbon sources on the production of cellulase by Phlebia gigantea," Enzyme and Microbial Technology, vol. 40, no. 6, pp. 1464-1468, 2007.

[44] S. Shikata, K. Saeki, H. Okoshi et al., "Alkaline cellulase for laundry detergents: production by alkalophilic strains of Bacillus and some properties of crude enzymes," Agricultural Biology and Chemistry, vol. 52, pp. 91-96, 1990.

[45] A. Balamurugan, R. Jayanthi, P. Nepolean, R. V. Pallavi, and R. Premkumar, "Studies on cellulose degrading bacteria in tea garden soils," African Journal of Plant Science, vol. 5, no. 1, pp. 22-27, 2011. 

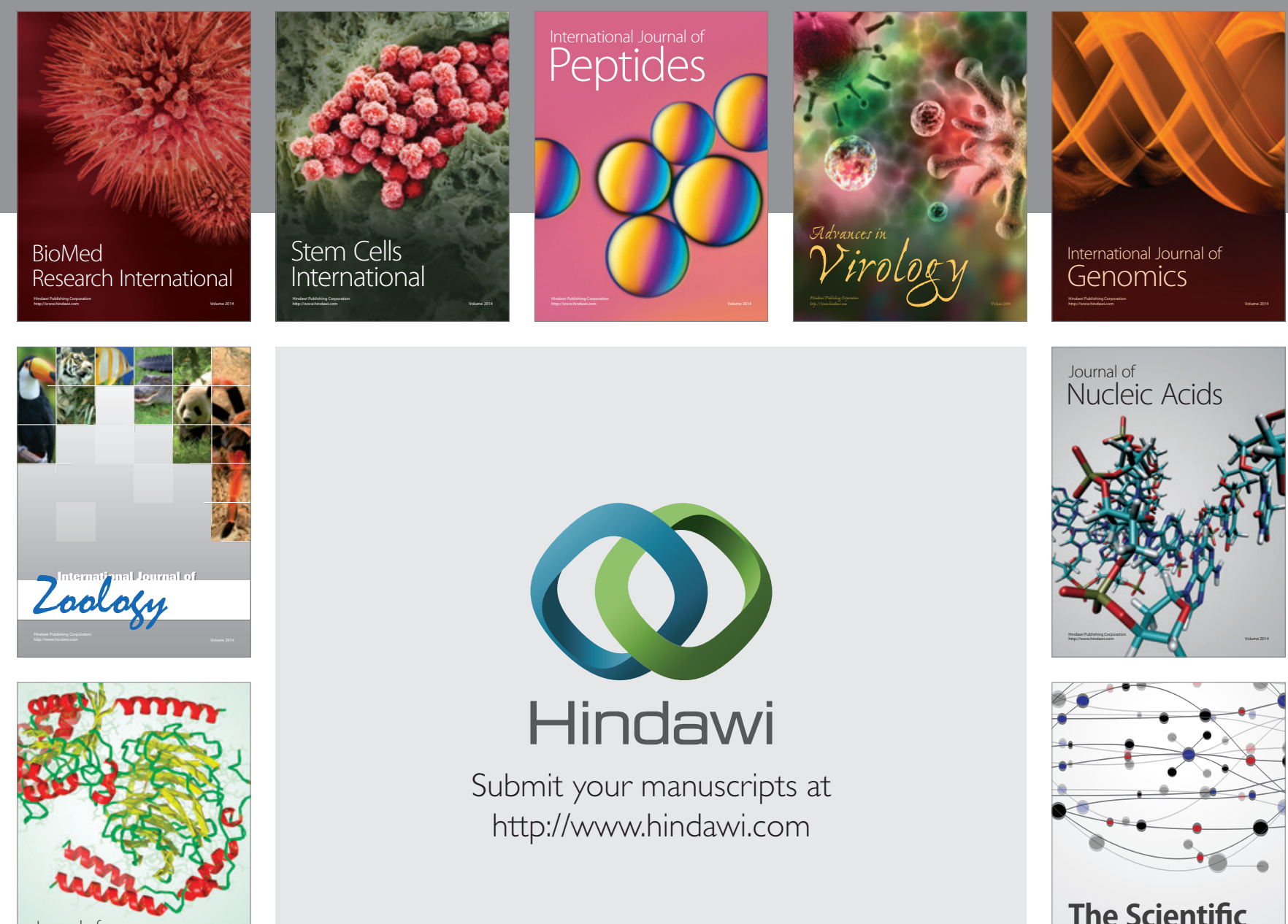

Submit your manuscripts at

http://www.hindawi.com

Journal of
Signal Transduction
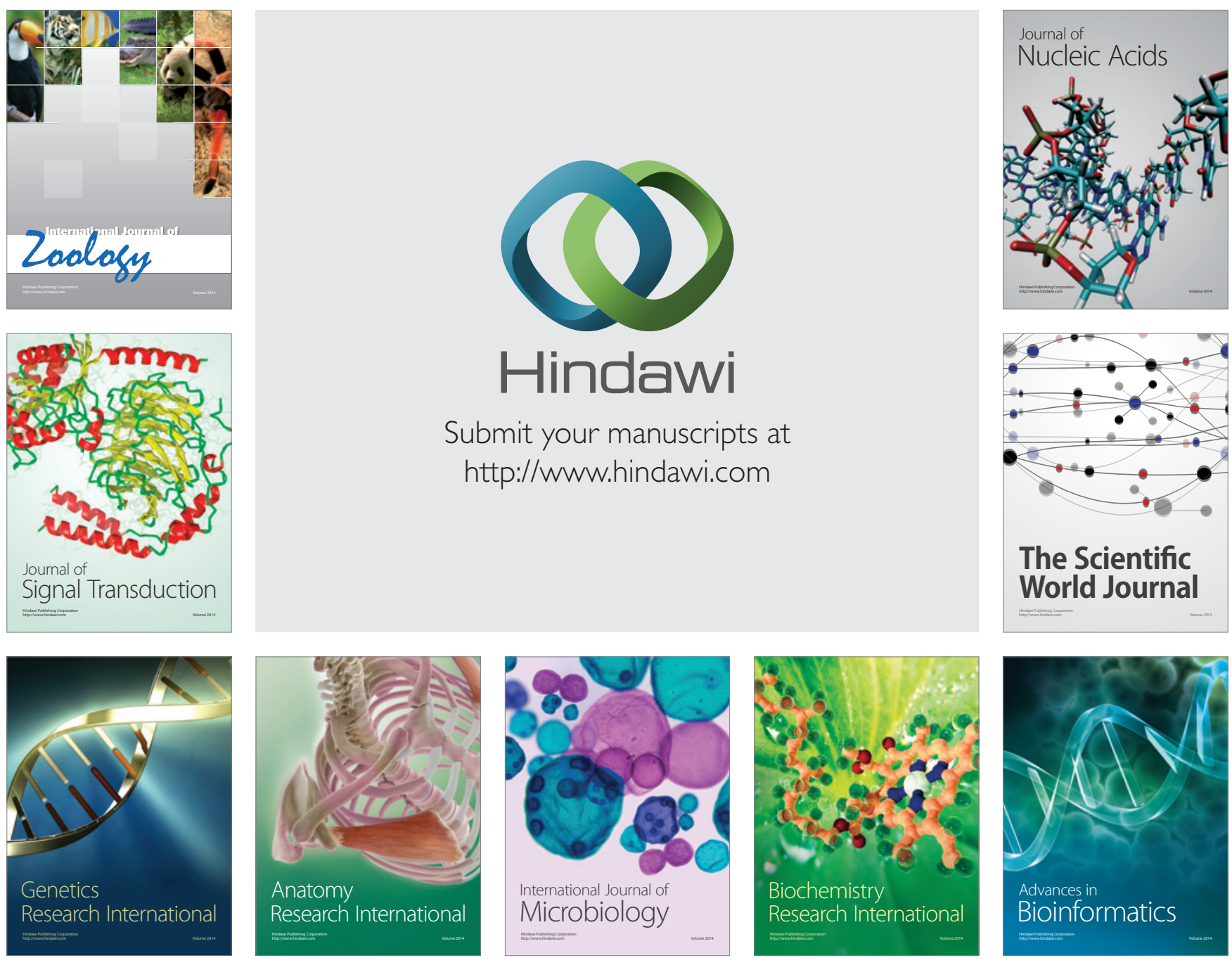

The Scientific World Journal
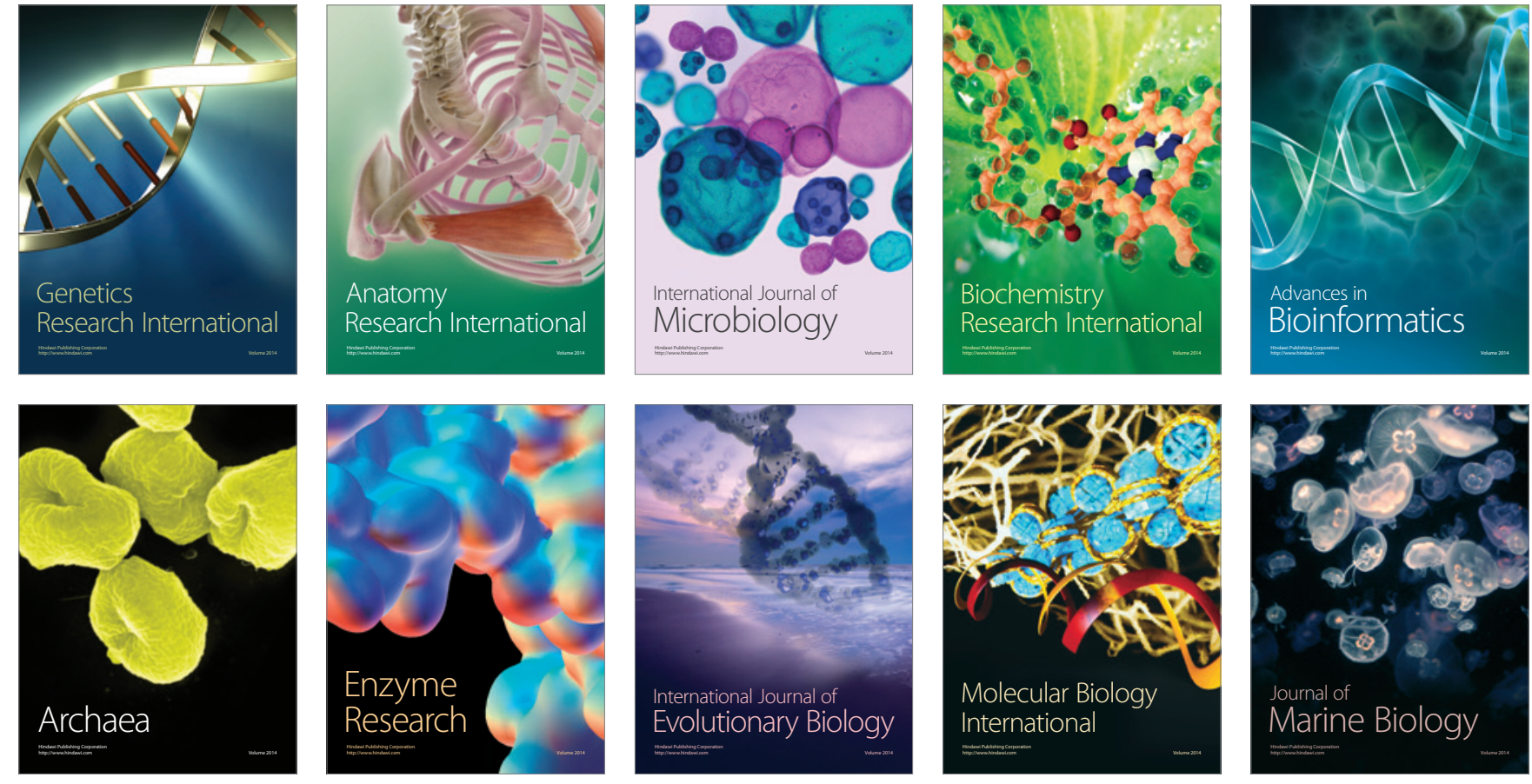